\title{
PREFERENSI KONSUMEN TERHADAP EMPAT VARIETAS UNGGUL MANGGA INDONESIA BERDASARKAN RESPON EMOSI
}

\author{
[Consumers Preference Based on Emotional Responses Toward \\ Four Indonesian Superior Mango Cultivars]
}

\author{
Rizqi Sofi Nur Fitriyah ${ }^{1) \star}$, Christofora Hanny Wijaya ${ }^{2)}$, dan Budi Nurtama ${ }^{2)}$ \\ 1) Program Studi IImu Pangan, Sekolah Pascasarjana, IPB University, Bogor \\ 2) Departemen Ilmu dan Teknologi Pangan, Fakultas Teknologi Pertanian, IPB University, Bogor
}

Diterima 10 Agustus 2021 / Disetujui 15 Desember 2021

\begin{abstract}
Understanding the consumer preferences and needs for new products is really important to support the acceptance and marketing success of a product. This study associated the preferences with emotional responses to various ready-to-eat and fresh food products. The objective was to obtain the preference based on emotional responses from different superior mango cultivars named agri gardina 45 (AG), gadung 21 (GD), red garifta (GM) and orange garifta (GO). The preference profile was measured by the 9point hedonic scale, while the emotional response by EsSense25 combined with rating questionnaire and 5-point scale. This study involved 108 panelists. The finding showed that consumers liked gadung and orange garifta, while slighlty liked agri gardina and red garifta. Additionally, the EsSense25's response showed that 4 out of 25 emotional terms were significantly different among the cultivars, namely happy, joyful, satisfied, and disgusted. However, fifteen attributes among the 25 emotion terms strongly correlated with liking, with the strongest terms on joyful, happy, satisfied, interested, secure, and free. These six emotions were associated with garifta orange, one of the newly released cultivars. The results suggested that garifta orange is potentially well-accepted and commercialized widely.
\end{abstract}

Keywords: consumers preference, emotion, EsSense25, mango

\begin{abstract}
ABSTRAK
Pemahaman minat dan kebutuhan konsumen terhadap sesuatu yang baru sangat penting untuk mendukung penerimaan dan keberhasilan pemasaran produk. Penelitian ini mengkaitkan preferensi dengan respon emosi, baik pada produk pangan siap saji maupun produk segar. Penelitian ini bertujuan untuk memperoleh preferensi berdasarkan respon emosional dari berbagai varietas mangga unggul yaitu agri gardina $45(\mathrm{AG})$, gadung 21 (GD), garifta merah (GM) dan garifta oranye (GO). Profil preferensi diukur dengan skala hedonik 9 poin, sedangkan respon emosional diukur dengan daftar istilah EsSense25 yang dikombinasikan dengan kuesioner rating skala 5 poin. Penelitian ini melibatkan 108 panelis. Hasil penelitian menunjukkan bahwa gadung dan garifta oranye disukai oleh konsumen, sedangkan agri gardina dan garifta merah hanya agak disukai. Penilaian EsSense25 menunjukkan 4 dari 25 istilah emosional memiliki perbedaan yang signifikan antar varietas, istilah tersebut yang terdiri dari senang, gembira, puas, dan jijik. Sejumlah 15 dari 25 istilah emosi memiliki korelasi positif yang kuat dengan kesukaan, korelasi terkuat terutama pada emosi gembira, senang, puas, tertarik, aman, dan bebas. Keenam emosi tersebut terasosiasi dengan garifta oranye, salah satu varietas yang baru dirilis. Varietas ini berpotensi diterima dengan baik oleh konsumen untuk dapat dikomersialisasikan secara luas.
\end{abstract}

Kata kunci: emosi, EsSense25, mangga, preferensi konsumen

\footnotetext{
*Penulis Korespondensi: Email: sofi_rq@apps.ipb.ac.id
} 


\section{PENDAHULUAN}

Indonesia merupakan negara dengan produksi buah mangga yang melimpah. Pada sekitar tahun 1990an Indonesia pernah mengekspor mangga arumanis 143 ke beberapa negara tetangga, namun setelah beberapa waktu terdapat pergeseran minat pembeli. Konsumen lebih menyukai mangga berkulit merah seperti mangga Alphonso dari India dan Tommy Atkins dari Meksiko (Rebin et al., 2016). Pengembangan varietas mangga sudah berlangsung sejak tahun 1980an. Berbagai varietas mangga telah dilepaskan sebagai varietas unggulan. Salah satu jenis varietas unggul merah yang telah diekspor adalah gedong gincu. Sayangnya, beberapa varietas yang dilepaskan tidak semuanya diminati oleh konsumen.

Pemahaman terkait minat dan kebutuhan konsumen terhadap sesuatu yang baru sangatlah penting karena mendukung proses penerimaan dan menentukan keberhasilan produk tersebut di pasaran. Presepsi konsumen sangatlah memengaruhi pilihan produk itu sendiri. Selain itu, Uswatun et al. (2014) menyebutkan gender dan kondisi multikultural masyarakat Indoneisa berpengaruh terhadap preferensi serta deteksi ambang rasa manis. Penelitian lainnya oleh Utami et al. (2020) menyebutkan penerimaan keseluruhan dari gedong gincu dipengaruhi oleh beberapa atribut sensori seperti kenampakan warna, tekstur, rasa, dan aromanya. Umumnya, preferensi ditentukan berdasarkan nilai kesukaan produk akan tetapi nilai kesukaan saja tidak cukup memberikan informasi pemilihan konsumen, sehingga diperlukan informasi tambahan untuk menentukan pilihan.

Penelitian sebelumnya mengkaitkan pilihan pangan dengan respon emosi terhadap berbagai produk pangan siap saji maupun produk segar. Studi terbaru menunjukkan bahwa makanan atau minuman yang dapat menimbulkan emosi berhubungan dengan preferensi konsumen dan preferensi produk seperti breakfast drink (Gutjar et al., 2014), jus buah dan sayur (Waehrens et al., 2018), cokelat (Gunaratne et al., 2019) dan wine (Mora et al., 2019). Pengujian respon emosional dapat dilakukan secara eksplisit dan implisit. Sebagian besar peneliti melakukan pengujian secara eksplisit menggunakan teknik verbal dan non-verbal. Teknik secara verbal menggunakan istilah emosi seperti EsSense Profile (King dan Meiselman, 2010), EsSense25 (Nestrud et al., 2016), istilah yang ditentukan oleh panelis atau self-reported (Samant dan Seo, 2019) dan istilah yang ditentukan peneliti (Cassani et al., 2020). Pada teknik non-verbal peneliti menggunakan gambar atau emotikon yang cenderung lebih mudah digunakan.
Tujuan penelitian ini adalah memperoleh preferensi konsumen terhadap ke empat varietas unggul mangga di Indonesia berdasarkan respon emosi serta rekomendasi alternatif varietas unggul mangga secara komersial.

\section{BAHAN DAN METODE}

\section{Bahan}

Bahan yang digunakan pada penelitian yaitu empat varietas unggul mangga yang telah dilepaskan dan terdaftar sebagai varietas unggul oleh Kementrian Pertanian berikut: agri gardina 45-AG (SK No. 125/Kpts/SR.120/D.2.7/3/2014), gadung 21GD (SK No. 121/Kpts/SR.120/D.2.7/12/2016), garifta merah-GM (SK No. 3344/Kpts/SR.120/9/2009), garifta oranye-GO (SK No. 3347/Kpts/SR.120/9/20 09) (Gambar 1). Buah tersebut diperoleh dari Kebun Percobaan Cukurgondang Kecamatan Grati Kabupaten Pasuruan Jawa Timur. Buah dipanen pada kondisi $80 \%$ kematangan dan dikirimkan ke Laboratorium Evaluasi Sensori Departemen IImu dan Teknologi Pangan (ITP) Bogor Jawa Barat. Pengiriman menggunakan jasa kargo selama \pm 3 hari melalui jalur darat. Selama pengiriman buah dikemas dalam kardus dengan penyekat untuk mencegah kerusakan buah.

\section{Metode}

Pengujian sensori dilakukan berdasarkan hasil kaji etik No. 259/IT3.KEPMSM-IPB/SK/2019 oleh Komisi Etik Penelitian yang Melibatkan Subyek Manusia Lembaga Penelitian dan Pengabdian kepada Masayarakat IPB (LPPM-IPB). Kelompok populasi yang menjadi target penelitian adalah populasi umum yang ditentukan dengan metode non-probability Sampling (pengambilan contoh tak berpeluang) dengan teknik purposive sampling (pengambilan contoh bertujuan). Jumlah panelis ditentukan menggunakan rumus Slovin (Sugiyono, 2019). Panelis yang dipilih merupakan naïve assessor yang menyukai buah mangga dan memiliki frekuensi konsumsi buah, serta memiliki tingkat stres yang rendahsedang. Tingkat stres ditentukan berdasarkan nilai perceived stress scale (skala stress yang dirasakan) oleh Cohen et al. (1983). Pengujian sensori berlangsung dengan teknik central location test (CLT), sehingga panelis diundang ke Laboratorium Evaluasi Sensori. Panelis telah mengisi dan menyetujui inform consent (form kesediaan keterlibatan pengujian).

\section{Persiapan pengujian}

Persiapan sampel diawali dengan penyortiran dan pencucian buah yang tiba di Laboratorium Evaluasi Sensori. Buah kemudian diseka hingga kering dan disimpan pada suhu ruang. 


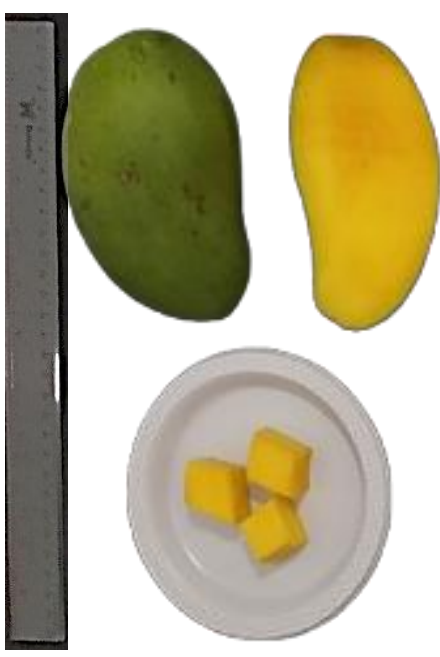

A
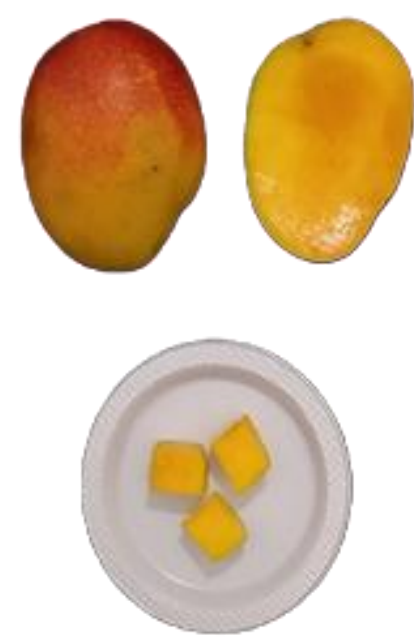

B
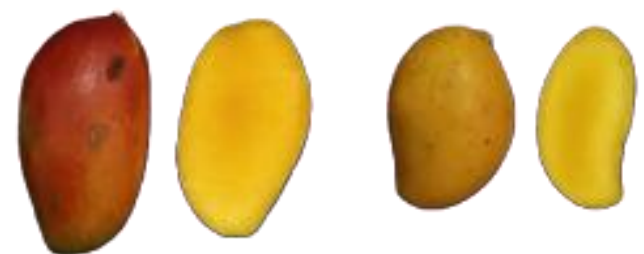

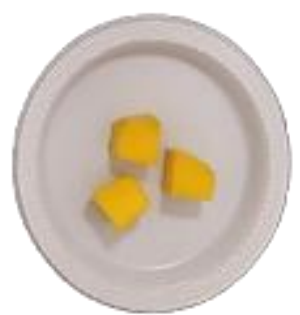

C

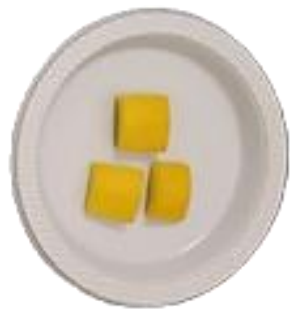

D

Keterangan: Gadung-1 (A), Garifta oranye (B), Garifta merah (C), Agri Gardina-45 (D)

Gambar 1. Kenampakan keempat varietas unggul mangga di Indonesia

Buah dikupas hingga bersih dan dipotong secara vertikal dari ujung hingga pangkal daging buah. Bagian tepi buah dengan ketebalan kurang dari $1 \mathrm{~cm}$ dipotong dan dihilangkan. Irisan tersebut dipotong dadu dengan ukuran $\pm 1,5 \times 1,5 \times 1,5 \mathrm{~cm}$. Sebanyak 3 potong buah disajikan dalam gelas transparan ukuran $50 \mathrm{~mL}$ yang sudah diberikan 3 digit kode acak. Sampel disajikan secara side by side (Lawless dan Heyman, 2010). Air mineral disediakan sebagai penetral indra pengecap selama pengujian.

\section{Pengujian preferensi dan respon emosi (Meilgaard et al., 2015; Nestrud et al., 2016)}

Panelis diminta mengisi kuisioner biodata, kuesioner perceived stress scale dan kuisioner survei varietas unggul mangga Indonesia untuk mendapatkan informasi pengenalan panelis terhadap vareitas yang diuji. Selanjutnya panelis melakukan pengujian sensori di booth yang disediakan secara blind tasting (tanpa informasi produk). Pertama panelis mengamati dan mencicipi sampel tanpa membandingkan dengan sampel lain. Pada saat mencicipi panelis diminta untuk menetralkan indra pengecap setiap berganti sampel menggunakan air mineral. Panelis memberikan penilaian preferensi menggunakan skala hedonik 9 poin $(1=$ amat sangat tidak suka sampai $9=$ amat sangat suka) (Meilgaard et al., 2015). Selanjutnya panelis menguji respon emosi menggunakan daftar istilah EsSense25 (Nestrud et al., 2016) yang diterjemahkan ke dalam bahasa Indonesia dan dikombinasikan dengan kuisioner Rate All That Apply (RATA). RATA merupakan varian metode Check-All-That-Apply (CATA) yaitu pengujian sensori deskriptif menggu- nakan daftar istilah yang telah ditentukan sebelumnya dengan pemberian rating intensitas oleh konsumen pada atribut atau daftar istilah yang menggambarkan karakteristik produk. Daftar istilah terdiri dari 16 respon emosi positif, 3 respon emosi negatif dan 6 repon emosi tidak terkategori (Tabel 1). Panelis diminta memilih dan memberikan penilaian dengan menggunakan skala intensitas 5 poin $(1=$ tidak sama sekali dan $5=$ sangat)

\section{Analisis data (Meilgaard et al., 2016; Meyners et al., 2016)}

Data penelitian yang diperoleh berupa profil panelis yang diolah menggunakan aplikasi microsoft excel, data preferensi diolah menggunakan ANOVA dengan uji lanjut Duncan $(P$-value 0,05$)$ pada aplikasi SPSS IBM 25. Data respon emosi diolah menggunakan Kruskal-Wallis dan uji lanjut Dunn dengan koreksi Bonferroni ( $P$-value 0,0083) pada aplikasi XLStat 2019. Data respon emosi dan atribut sensori dipetakan menggunakan principle component analysis (PCA) dengan aplikasi XLStat 2019.

\section{HASIL DAN PEMBAHASAN}

\section{Profil panelis}

Panelis pengujian berjumlah 108 orang yang terdiri dari 82 perempuan $(75 \%)$ dan 26 laki-laki (25\%) dengan rentang usia 18-36 tahun. Sebagian besar panelis berasal dari Jawa dan Bali (67\%), Sumatera (24\%), Kalimantan (5\%), serta Sulawesi (4\%). 
Tabel 1. Atribut respon emosi yang diterjemahkan ke bahasa Indonesia

\begin{tabular}{ccc}
\hline & Daftar istilah Emosi EsSense 25 & Negatif \\
\hline Positif & Tidak Terkategori & Bored (Bosan) \\
Active (Aktif) & Aggressive (Agresif) & Disgusted (Jijik) \\
Adventerous (Berani) & Guilty (Bersalah) & Worried (Cemas) \\
Calm (Tenang) & Mild (Lembut) & Free (Bebas) \\
Free (Bebas) & Tame (Lemah) & \\
Enthusiastic (Antusias) & Understanding (Pengertian) & \\
Good natured (Baik Hati) & Wild (Ribut) & \\
Good (Baik) & & \\
Happy (Senang) & & \\
Interested (Tertarik) & & \\
Joyful (Gembira) & & \\
Loving (Sayang) & & \\
Nostalgic (Nostalgia) & & \\
Pleasant (Nyaman) & & \\
Satisfied (Puas) & & \\
Secure (Aman) & & \\
Warm (Hangat) &
\end{tabular}

Keterangan: Sumber= Nestrud et al. (2016)

Berdasarkan hasil pengisian kuisioner, $72 \%$ panelis mengonsumsi buah 1-3 kali seminggu dan hampir keseluruhan panelis menyukai buah mangga. Survei informasi varietas unggul mangga di Indonesia menunjukkan 57\% panelis mengetahuinya. Terdapat $49 \%$ panelis mengetahui tentang varietas mangga merah. Diantara 6 jenis varietas mangga unggul yang disurvei (arumanis, gadung, garifta merah, garifta orange, agri gardina dan denarum) terdapat $20 \%$ panelis mengetahui mangga arumanis dan $11 \%$ panelis mengetahui mangga gadung serta $58 \%$ panelis menyebutkan keduanya. Selain itu, $6 \%$ panelis mengetahui mangga garifta dan hanya $1 \%$ yang menyebutkan garifta merah dan oranye serta tidak ada panelis yang mengenali varietas agri gardina dan denarum. Empat varietas (gadung, agri gardina, garifta merah dan oranye) digunakan pada pengujian sedangkan arumanis dan den arum tidak dilakukan pengujian.

Hasil survei juga menunjukkan diantara empat varietas mangga yang diuji sebagian besar panelis mengenali gadung sebagai varietas unggul. Sementara hanya sebagian kecil yang mengenali garifta dan tidak ada panelis yang mengenali agri gardina. Hal ini kemungkinan disebabkan gadung yang telah dikembangkan sejak tahun 1994 dan dilepaskan sebagai varietas unggul pada 2016 (Karsinah et al., 2017), sehingga panelis lebih familiar terhadap varietas gadung. Varietas agri gardina baru dikembangkan pada tahun 2003 dan dilepaskan sebagai varietas unggul pada tahun 2014 (Karsinah, 2014). Kondisi tersebut menunjukkan bahwa proses pengujian berlangsung secara blind tasting.

\section{Preferensi terhadap keempat varietas unggul mangga}

Sebaran data preferensi kesukaan (Gambar 2) menunjukkan varietas gadung (GD) adalah yang paling baik diikuti dengan garifta orange (GO) dengan total persentasi frekuensi preferensi suka $(74,07 \%)$ hingga amat sangat suka $(72,22 \%)$. Varietas garifta merah (GM) dan agri gardina (AG) cenderung memperoleh penilaian kurang disukai dengan total frekuensi preferensi kesukaan agak suka $(64,81 \%)$ hingga amat tidak suka $(52,78 \%)$. Hasil tersebut menunjukkan GD lebih disukai oleh panelis, kemungkinan besar karena GD sudah sering dikonsumsi panelis. Disisi lain, penerimaan panelis terhadap varietas yang masih baru yaitu GO, mendekati varietas GD yang lebih dikenali panelis. Varietas baru lainnya yaitu GM dan AG nampaknya kurang diminati panelis. Menurut hasil survei ketiga varietas tersebut kurang dikenali, sehingga diduga panelis memberikan penilaian kesukaan yang lebih rendah. Hasil tersebut didukung dengan penelitian Appleton et al. (2019) yaitu asupan dan kesukaan yang tinggi pada sayuran disebabkan adanya pengalaman paparan positif dari produk serta adanya keakraban terhadap sayuran tersebut.

Fenomena sebaran frekuensi kesukaan (Gambar 2) didukung dengan hasil penerimaan hedonik (Tabel 2). Varietas GD dan GO berbeda nyata dengan tingkat kesukaan $A G$ dan GM. GD dan GO memiliki tingkat kesukaan lebih tinggi (suka) dibandingkan AG dan GM (agak suka). Hasil pengujian ini menunjukkan bahwa GO seperti halnya GD berpotensi untuk dipasarkan lebih luas sementara Varietas AG dan GM cenderung kurang diminati yang disebabkan karakteristik sensori varietas $A G$ dan GM. Tekstur AG yang mudah hancur dan GM yang cenderung memiliki rasa asam dengan aroma buah yang kurang masak (Fitriyah, 2021). Seperti penelitian Santagiuliana et al. (2019) produk makanan baru dengan tingkat kesukaan yang berbeda dipengaruhi oleh karakteristik tekstur produk serta bergantung pada ekspektasi konsumen terhadap karakteristik sensorinya. 


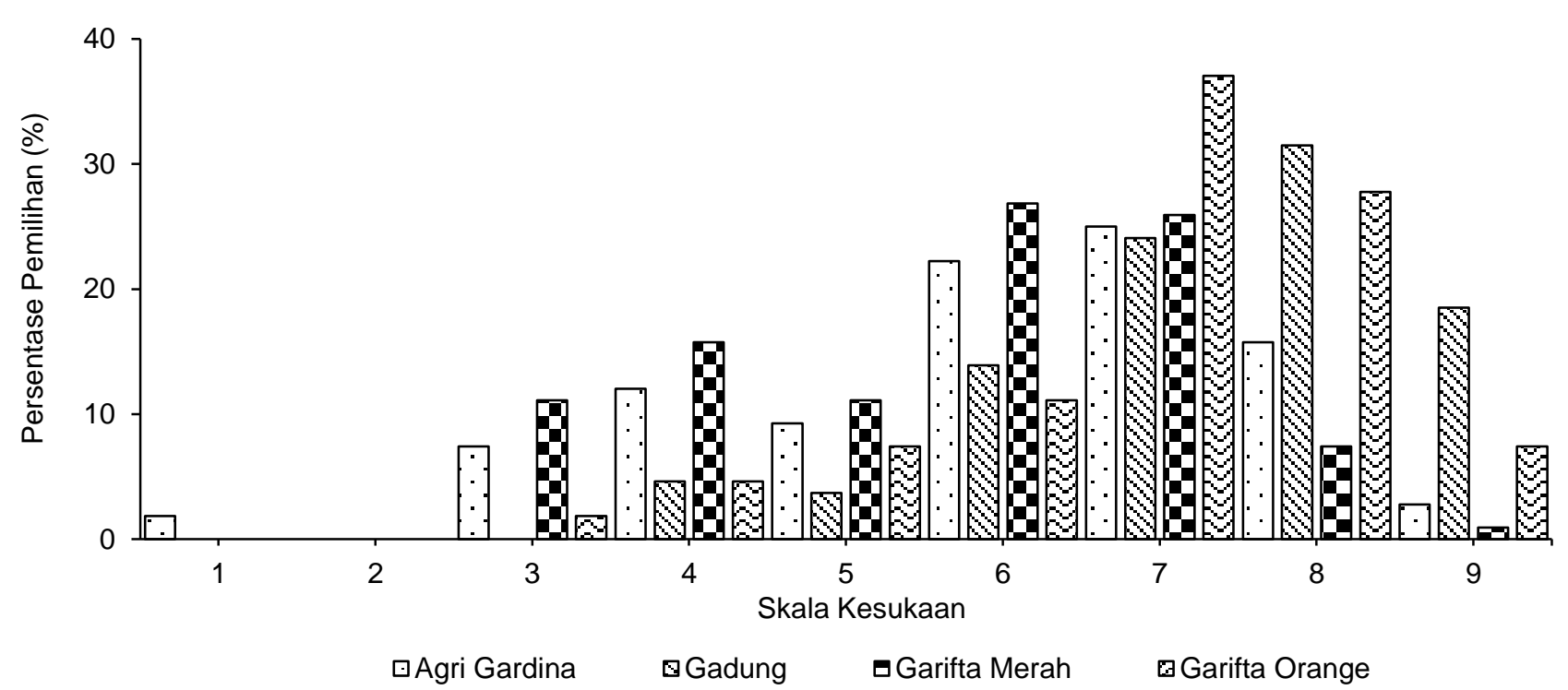

Gambar 2. Frekuensi pemilihan nilai kesukaan panelis terhadap keempat varietas unggul mangga

Tabel 2. Nilai kesukaan keempat varietas unggul mangga Indonesia

\begin{tabular}{lc}
\hline \multicolumn{1}{c}{ Sampel } & Kesukaan \\
\hline Agri gardina 45 & $6,00^{\mathrm{a}} \pm 1,71$ \\
Gadung 21 & $7,35^{\mathrm{b}} \pm 1,31$ \\
Garifta merah & $5,67^{\mathrm{a}} \pm 1,52$ \\
Garifta oranye & $6,95^{\mathrm{b}} \pm 1,33$ \\
\hline
\end{tabular}

Keterangan: Nilai merupakan rerata \pm standar deviasi yang diikuti dengan huruf yang sama menunjukkan tidak berbeda nyata $(P$-value 0,05$)$ dengan uji beda Duncan

\section{Respon emosi yang muncul terhadap varietas agri gardina, gadung, garifta merah dan garifta orange}

Sebagian besar panelis memberikan respon emosi positif terhadap keempat varietas (Gambar 3). Emosi positif yang paling banyak dipilih adalah senang $(64,81 \%)$, aktif $(56,48 \%)$ dan sayang $(54,63 \%)$. Tren pemilihan respon emosi keempat varietas cenderung mirip, terutama GD dengan GO serta GM dengan AG. Hasil ini konsisten dengan penilaian preferensinya. Respon emosi positif yang paling banyak muncul adalah senang pada GD dan GO serta aktif dan sayang pada GD. Penelitian sebelumnya melaporkan utamanya konsumen akan merasakan emosi positif dalam merespon makanan, hal ini akibat adanya disposisi respon afektif positif terhadap sebagian besar makanan komersial (Cardello et al., 2012; Manzocco et al., 2013; Borgogno et al. 2017; Yang et al. 2020). Penelitian lainnya Yang et al. (2020) menyebutkan makanan yang manis dapat memicu munculnya respon emosi positif serta pengujian tanpa mengenali produk menghasilkan respon yang cenderung positif.

Pemilihan respon emosi negatif dan tidak terkategori hasilnya cukup rendah, masing-masing sebesar 7,41-27,78 dan 10,19-25,93\%. Emosi nega- tif yang paling banyak dipilih adalah bosan pada AG, sedangkan emosi tidak terkategori paling banyak dipilih adalah lemah pada GD. Kedua kategori respon tersebut memiliki tren pemilihan yang cenderung berbeda antar varietas. Fenomena tersebut diduga akibat perbedaan karakteristik sensori yang memengaruhi munculnya respon emosi. Seperti penelitian $\mathrm{Ng}$ et al. (2013) menyebutkan bubur standar yang lebih manis memicu munculnya emosi positif daripada bubur yang tidak ditambahkan gula. Selain itu, menurut Schifferstein et al. (2013) perbedaan sensori (kenampakan, aroma dan rasa) dapat memengaruhi munculnya respon emosi.

Data pada Tabel 3 menunjukkan empat dari 25 respon emosi berbeda signifikan ( $P$-value 0,05$)$ yang terdiri dari 3 emosi positif (senang, gembira dan puas) dan 1 emosi negatif (jijik). Hasil penelitian ini tidak jauh berbeda dengan Mora et al. (2019) yaitu pada pengujian 5 jenis wine hanya 5 dari 26 respon emosi berbeda signifikan. Selanjutnya, penelitian Dorado et al. (2016) menyebutkan pada pengujian produk cokelat hanya terdapat 7 dari 38 respon emosi berbeda signifikan.

GD sebagai varietas yang disukai dan dikenali mendapatkan respon positif, terutama pada emosi senang, gembira dan puas. Diantara tiga varietas unggul mangga yang kurang dikenali, GO dan GM cenderung memunculkan respon yang positif dan netral, sedangkan AG memicu respon yang negatif. Hasil ini menunjukkan preferensi yang sama dapat memunculkan respon emosi yang berbeda. Hal ini seperti pada penelitian Spinelli et al. (2019) menyebutkan konsumen dengan pola preferensi yang berbeda memunculkan respon emosi yang berbeda. Penelitian ini juga membuktikan respon emosi lebih baik dalam membedakan keempat varietas daripada nilai kesukaan saja. 


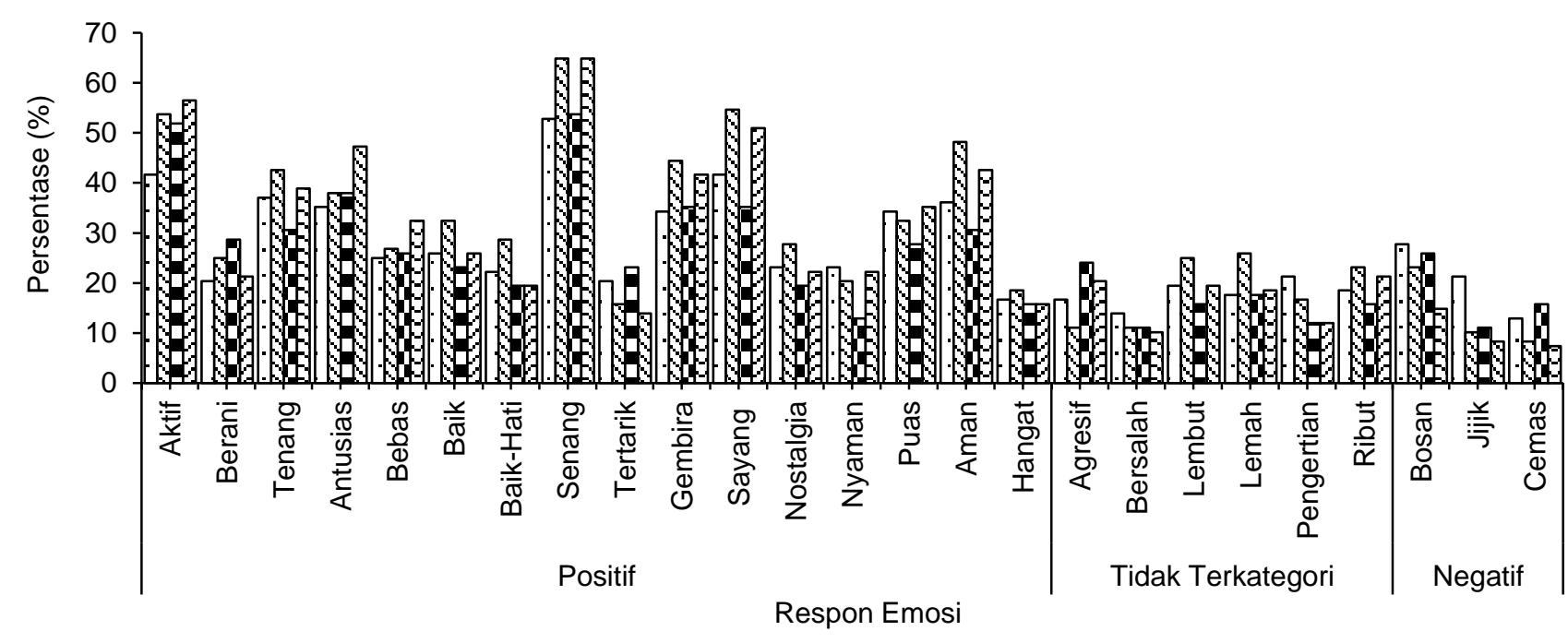

$\square$ Agri Gardina घGadung घGarifta Merah घGarifta Orange

Gambar 3. Frekuensi pemilihan respon emosi panelis terhadap keempat varietas unggul mangga

Tabel 3. Respon emosi keempat varietas mangga unggul Indonesia

\begin{tabular}{lcccc}
\hline \multirow{2}{*}{ Respon Emosi } & \multicolumn{3}{c}{ Varietas } \\
\cline { 2 - 5 } & Agri Gardina & Gadung & Garifta Merah & Garifta Oranye \\
\hline Aktif & $1,91 \pm 1,20$ & $2,38 \pm 1,46$ & $2,18 \pm 1,28$ & $2,37 \pm 1,34$ \\
Berani & $1,36 \pm 0,86$ & $1,52 \pm 1,02$ & $1,55 \pm 1,00$ & $1,42 \pm 0,89$ \\
Agresif & $1,30 \pm 0,78$ & $1,23 \pm 0,74$ & $1,51 \pm 1,01$ & $1,40 \pm 0,89$ \\
Bosan & $1,45 \pm 0,83$ & $1,35 \pm 0,72$ & $1,46 \pm 0,87$ & $1,24 \pm 0,64$ \\
Tenang & $1,84 \pm 1,23$ & $1,94 \pm 1,23$ & $1,63 \pm 1,06$ & $1,86 \pm 1,21$ \\
Jijik* $_{\text {Antusias }}$ & $1,37^{\mathrm{b}} \pm 0,85$ & $1,19^{\mathrm{ab}} \pm 0,68$ & $1,15^{\mathrm{ab}} \pm 0,47$ & $1,11^{\mathrm{a}} \pm 0,42$ \\
Bebas & $1,83 \pm 1,29$ & $1,97 \pm 1,36$ & $1,91 \pm 1,29$ & $2,11 \pm 1,36$ \\
Baik & $1,54 \pm 1,04$ & $1,60 \pm 1,11$ & $1,47 \pm 0,87$ & $1,67 \pm 1,09$ \\
Baik Hati & $1,64 \pm 1,17$ & $1,87 \pm 1,38$ & $1,53 \pm 1,05$ & $1,65 \pm 1,18$ \\
Bersalah & $1,52 \pm 1,10$ & $1,68 \pm 1,23$ & $1,43 \pm 0,96$ & $1,44 \pm 0,99$ \\
Senang & $1,25 \pm 0,70$ & $1,19 \pm 0,60$ & $1,21 \pm 0,64$ & $1,18 \pm 0,58$ \\
Cemas & $2,19^{\mathrm{a}} \pm 1,30$ & $2,69^{\mathrm{ab}} \pm 1,45$ & $2,19^{\mathrm{a}} \pm 1,23$ & $2,71^{\mathrm{b}} \pm 1,43$ \\
Tertarik & $1,34 \pm 0,75$ & $1,30 \pm 0,78$ & $1,35 \pm 0,72$ & $1,24 \pm 0,67$ \\
Gembira* & $1,74 \pm 1,11$ & $2,01 \pm 1,29$ & $1,71 \pm 1,06$ & $2,06 \pm 1,38$ \\
Sayang & $1,96^{\mathrm{a}} \pm 1,27$ & $2,32^{\mathrm{b}} \pm 1,39$ & $1,78^{\mathrm{a}} \pm 1,18$ & $2,29^{\mathrm{b}} \pm 1,40$ \\
Lembut & $1,43 \pm 0,95$ & $1,53 \pm 1,05$ & $1,32 \pm 0,82$ & $1,41 \pm 0,93$ \\
Nostalgia & $1,81 \pm 1,35$ & $1,68 \pm 1,21$ & $1,38 \pm 0,88$ & $1,52 \pm 1,06$ \\
Nyaman & $1,57 \pm 1,15$ & $1,51 \pm 1,14$ & $1,27 \pm 0,77$ & $1,50 \pm 1,06$ \\
Puas* & $1,81 \pm 1,27$ & $1,81 \pm 1,32$ & $1,57 \pm 1,05$ & $1,81 \pm 1,25$ \\
Aman & $1,85^{\mathrm{ab}} \pm 1,30$ & $2,22^{\mathrm{b}} \pm 1,44$ & $1,55^{\mathrm{a}} \pm 0,95$ & $2,01^{\mathrm{ab}} \pm 1,33$ \\
Lemah & $1,40 \pm 0,96$ & $1,57 \pm 1,07$ & $1,37 \pm 0,87$ & $1,43 \pm 1,01$ \\
Pengertian & $1,42 \pm 0,92$ & $1,23 \pm 0,62$ & $1,19 \pm 0,60$ & $1,18 \pm 0,54$ \\
Hangat & $1,37 \pm 0,90$ & $1,44 \pm 1,04$ & $1,33 \pm 0,88$ & $1,31 \pm 0,80$ \\
Ribut & $1,43 \pm 1,00$ & $1,57 \pm 1,11$ & $1,29 \pm 0,76$ & $1,39 \pm 0,86$ \\
\hline Keman & $1,22 \pm 0,67$ & $1,11 \pm 0,40$ & $1,30 \pm 0,76$ & $1,12 \pm 0,47$
\end{tabular}

Keterangan: Nilai skala $1=$ tidak sama sekali dan $5=$ sangat. Rata-rata \pm standar deviasi yang diikuti dengan tanda $\left(^{*}\right)$ menunjukkan berbeda signifikan ( $p$-value 0,05$)$ dengan uji Kruskal-Wallis. Angka yang diikuti huruf yang sama pada baris yang sama tidak berbeda signifikan berdasarkan uji lanjut Dunn dengan koreksi Bonferroni $(P$-value 0,0083$)$

Profil respon emosi varietas agri gardina, gadung, garifta merah dan garifta oranye

Varietas GO berada satu plot dengan GD pada dimensi pleasant-valence (sifat menyenangkan) yaitu pada kuadran I dan II, sedangkan AG berada satu plot dengan GM pada dimensi unpleasantvalence (sifat tidak menyenangkan) yaitu kuadran III dan IV. Gambar 4 tersebut mengindikasikan masingmasing varietas mampu membangkitkan respon emosi yang berbeda. Hasil pemetaan tersebut konsisten dengan penilaian preferensi. Namun, hanya varietas GO yang berada satu kuadran dengan nilai kesukaan, sehingga diasumsikan GO lebih diminati. Sebagai varietas yang masih baru GO juga ber- 
potensi untuk dipilih konsumen ketika dilepaskan di pasaran. Menurut Gutjar et al. (2015) kombinasi kesukaan dan valence memberikan nilai prediksi terkuat berdasarkan rasa produk. Selain itu, emosi yang ditimbulkan makanan dapat menambah nilai prediktif daripada hanya nilai kesukaan serta menunjukkan prilaku konsumen dalam pemilihan produk.

Hasil pemetaan menginformasikan preferensi yang sama dapat memunculkan respon emosi yang berbeda. Pada preferensi disukai respon emosi GD mengindikasikan konsumen familiar dengan buah tersebut, seperti munculnya respon puas, aman, tenang, nyaman, baik dan nostalgia. Respon emosi pada GO mengindikasikan ketertarikan konsumen terhadap varietas. Respon yang muncul seperti aktif, tertarik dan antusias. Respon tersebut juga memiliki intensitas aktivasi yang lebih tinggi yang diduga dapat meningkatkan minat konsumen dalam pilihan akhir konsumen.

Pada preferensi agak disukai varietas AG dan GM cenderung membangkitkan respon negatif. Respon pada AG seperti jijik, bersalah dan bosan menunjukkan kurangnya minat panelis. Respon tersebut muncul diduga akibat tekstur dan penampilannya yang kurang menarik. Diantara keempat varietas AG memiliki daging buah yang tipis, hal ini menyebabkan tekstur daging buah mudah hancur dan rusak saat dipotong. Hal tersebut seperti yang dilaporkan oleh Karsinah et al. (2014) bahwa mangga Agri Gardina 45 memiliki daging buah yang tipis dan mudah hancur. Peneltitian lainnya oleh Yang et al. (2020) menyebutkan karakteristik tekstur produk akhir dapat berkontribusi terhadap munculnya respon emosi.

Grafik biplot PCA (Gambar 4) juga memperlihatkan korelasi antar respon emosi dengan kesukaan. Terdapat 15 dari 25 respon emosi berkorelasi positif kuat dengan nilai kesukaan (Tabel 4). Hasil korelasi tersebut mengindikasikan respon emosi sangat berpengaruh dalam menentukan preferensi atau minat panelis terhadap varietas unggul mangga. Fenomena keterkaitan pemahaman perasaan atau kesukaan dengan respon emosi saat mengonsumsi produk dapat menentukan pilihan pembelian daripada hanya mengukur nilai kesukaan telah dilaporkan oleh (King et al., 2013; Spinelli et al., 2014; Chaya et al., 2015; Yang et al., 2020).

Hasil perolehan korelasi positif antara nilai kesukaan dengan respon positif seperti bahagia, senang, puas dan tertarik serta korelasi negatif dengan respon negatif seperti jijik, bersalah dan bosan didukung dengan penelitian Samant et al. (2017) pada pengujian larutan rasa dasar terdapat korelasi positif antara nilai kesukaan dengan respon aktif, baik, puas dan nostalgia serta korelasi negatif antara jijik dengan nilai kesukaan. Penelitian lainnya oleh Samant dan Seo (2019) pada pengujian jus sayuran secara individu memperlihatkan korelasi positif antara kesukaan dengan emosi positif puas dan senang, serta korelasi yang negatif pada emosi bosan dan jijik.

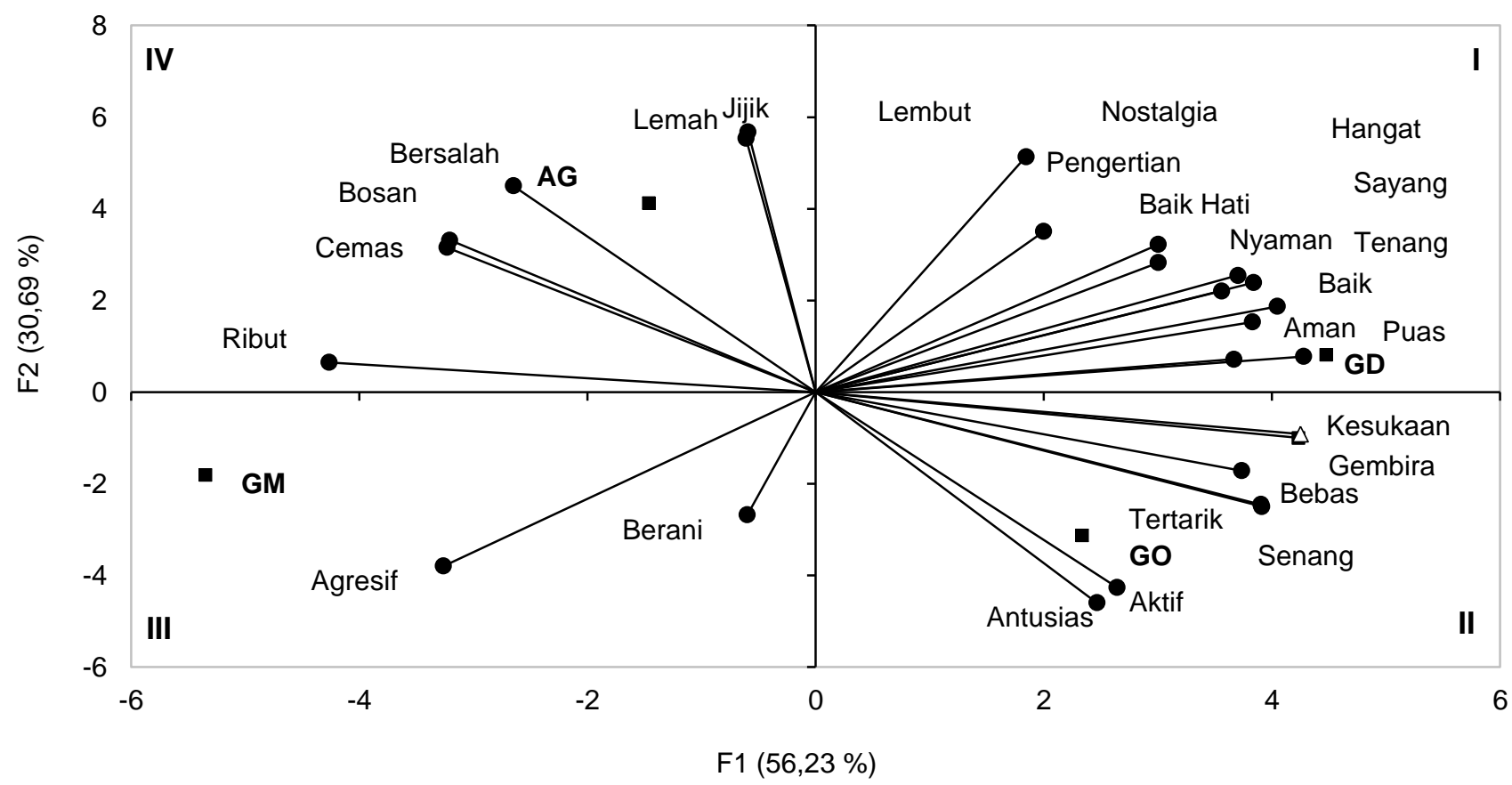

Keterangan: $=$ Variabel aktif; $\square=$ Variabel observasi; $\Delta=$ Variabel tambahan

Gambar 4. Profil respon emosi berdasarkan biplot PCA keempat varietas unggul mangga 
Tabel 4. Korelasi antara nilai kesukaan dengan respon emosi

\begin{tabular}{|c|c|c|}
\hline $\begin{array}{c}\text { Istilah Respon } \\
\text { Emosi }\end{array}$ & Pearson's r & $\begin{array}{l}\text { Kategori } \\
\text { Korelasi }\end{array}$ \\
\hline Bahagia & 0,980 & Kuat \\
\hline Senang & 0,958 & Kuat \\
\hline Puas & 0,952 & Kuat \\
\hline Tertarik & 0,946 & Kuat \\
\hline Aman & 0,866 & Kuat \\
\hline Baik & 0,865 & Kuat \\
\hline Bebas & 0,851 & Kuat \\
\hline Tenang & 0,847 & Kuat \\
\hline Sayang & 0,823 & Kuat \\
\hline Hangat & 0,795 & Kuat \\
\hline Aktif & 0,757 & Kuat \\
\hline Nyaman & 0,695 & Kuat \\
\hline Antusias & 0,667 & Kuat \\
\hline Baik Hati & 0,657 & Kuat \\
\hline Nostalgia & 0,535 & Kuat \\
\hline Agresif & $-0,639$ & Kuat \\
\hline Bersalah & $-0,751$ & Kuat \\
\hline Cemas & $-0,782$ & Kuat \\
\hline Bosan & $-0,784$ & Kuat \\
\hline Ribut & $-0,972$ & Kuat \\
\hline Pengertian & 0,423 & Sedang \\
\hline Jijik & $-0,322$ & Sedang \\
\hline Lemah & $-0,332$ & Sedang \\
\hline Lembut & 0,244 & Lemah \\
\hline Berani & 0,039 & Lemah \\
\hline
\end{tabular}

Keterangan: Kriteria diberikan berdasarkan Cohen's (2013). Nilai dengan angka tebal tidak berbeda dari 0 dengan level signifikan $95 \%$

Secara umum, hasil penelitian membuktikan bahwa respon emosi mampu memberikan informasi yang tidak diperoleh dari nilai kesukaan saja. Informasi tersebut membantu dalam memahami preferensi ataupun pilihan konsumen terhadap varietas unggul mangga. Kombinasi nilai kesukaan dan respon emosi memberikan informasi prediksi pilihan yang lebih baik. Produk dengan kualitas baik akan lebih mudah dipasarkan apalagi dengan melihat preferensi diatas menunjukkan garifta oranye berpotensi seperti halnya gadung untuk di pasarkan lebih luas. Teknologi pemasaran dewasa ini juga berkembang sangat pesat, pemanfaatan media digital akan menunjang penyebaran informasi terkait varietas unggul mangga merah yang saat ini masih dikembangkan oleh Balitbu Tropika di Pasuruan serta dapat meningkatkan dan memperluas jangkauan target pemasarannya.

\section{KESIMPULAN}

Preferensi mengelompokkan keempat varietas unggul mangga menjadi yang disukai (gadung dan garifta oranye) serta yang agak disukai (agri gardina dan garifta merah). Respon emosi senang, gembira, puas dan jijik membedakan varietas secara signifikan. Informasi tersebut membantu memahami pre- ferensi ataupun pilihan konsumen terhadap varietas unggul mangga. Respon emosi yang muncul pada varietas yang disukai menunjukkan bahwa panelis familiar dengan gadung dan tertarik dengan garifta oranye. Pada garifta merah dan agri gardina respon emosinya cenderung netral dan negatif. Pemetaan respon emosi dan nilai kesukaan memberikan informasi prediksi pilihan yang lebih baik. Informasi tersebut menunjukkan garifta oranye memiliki potensi yang sama dengan gadung. Kombinasi nilai kesukaan dan respon emosi menunjukkan garifta oranye dan gadung dapat direkomendasikan sebagai varietas yang berpotensi untuk dikomersialkan secara luas dibandingkan dengan agri gardina dan garifta merah.

\section{DAFTAR PUSTAKA}

Appleton KM, Dinnella C, Spinelli S, Morizet D, Saulais L, Hemingway A, Monteleone E, Depezay L, Perez-Cueto FJA, Hartwell H. 2019. Liking and consumption of vegetables with more appealing and less appealing sensory properties: Associations with attitudes, food neophobia and food choice motivations in European adolescents. Food Qual Prefer 75: 179-186. DOI: 10.1016/j.foodqual.2019.02.007.

Borgogno M, Cardello AV, Favotto S, Piasentier E. 2017. An emotional approach to beef evaluation. Meat Sci 127: 1-5. DOI: 10.1016/j. meatsci.2017.01.002.

Cardello AV, Meiselman HL, Schutz HG, Craig C, Given Z, Lesher LL, Eicher S. 2012. Measuring emotional responses to foods and food names using questionnaires. Food Qual Prefer 24: 243-250. DOI: 10.1016/j.foodqual.2011.12.002.

Cassani L, Fiszman S, Alvarez M V, Moreira MR, Laguna L, Tarrega A. 2020. Emotional response evoked when looking at and trying a new food product, measured through images and words. A case-study with novel fruit and vegetable smoothies. Food Qual Prefer 84: 103955. DOI: $10.1016 / j . f o o d q u a l .2020 .103955$.

Chaya $C$, Eaton $C$, Hewson L, Vázquez RF, Fernández-Ruiz V, Smart KA, Hort J. 2015. Developing a reduced consumer-led lexicon to measure emotional response to beer. Food Qual Prefer 45: 100-112. DOI: 10.1016/j. foodqual.2015.06.003.

Cohen J. 2013. Statistical Power Analysis. Edisi Kedua. 24. Lawrence Erlbaum Associates Inc, Hillsdale, NJ England. 
Cohen S, Kamarck T, Mermelstein R. 1983. A global measure of perceived stress. J Health Soc Behav 24: 385-396. DOI: 10.2307/2136404.

Dorado R, Pérez-Hugalde C, Picard A, Chaya C. 2016. Influence of first position effect on emotional response. Food Qual Prefer 49: 189-196. DOI: 10.1016/j.foodqual.2015.12.009.

Fitriyah RSN. 2021. Preferensi Berdasarkan Respon Emosional Konsumen terhadap Profil FisikoSensori Empat Varietas Unggul Mangga di Indonesia. [Tesis]. Bogor: Fakultas Teknologi Pertanian, Institut Pertanian Bogor

Gunaratne TM, Gonzalez Viejo C, Fuentes S, Torrico DD, Gunaratne NM, Ashman H, Dunshea FR. 2019. Development of emotion lexicons to describe chocolate using the CheckAll-That-Apply (CATA) methodology across Asian and Western groups. Food Res Int 115: 526-534. DOI: 10.1016/j.foodres.2018.10.001.

Gutjar S, Dalenberg JR, de Graaf C, de Wijk RA, Palascha A, Renken RJ, Jager G. 2015. What reported food-evoked emotions may add: A model to predict consumer food choice. Food Qual Prefer 45: 140-148. DOI: 10.1016/j. foodqual.2015.06.008.

Gutjar S, de Graaf C, Kooijman V, de Wijk RA, Nys A, Ter Horst GJ, Jager G. 2014. The role of emotions in food choice and liking. Food Res Int 76: 216-223. DOI: 10.1016/j.foodres.2014. 12.022 .

Karsinah, Rebin, Setyowati K. 2014. Varietas unggul baru mangga hibrid Agri Gardina 45. IPTEK Hortik (10): 44-48.

Karsinah, Rebin, Tasliah. 2017. Varietas unggul mangga Gadung 21: Daging buah tebal, berserat rendah, rasa manis, dan dapat dimakan seperti alpukat. IPTEK Hortik.(13): 3944.

Karsinah. 2014. Mangga hibrid Agri Gardina 45 genjah dan unik. www.litbang.pertanian.go.id/ info-teknologi/2064/ [18 Oktober 2020].

King SC, Meiselman HL, Thomas Carr B. 2013. Measuring emotions associated with foods: Important elements of questionnaire and test design. Food Qual Prefer 28: 8-16. DOI: 10.1016/j.foodqual.2012.08.007.

King SC, Meiselman HL. 2010. Development of a method to measure consumer emotions associated with foods. Food Qual Prefer 21: 168177. DOI: 10.1016/j.foodqual.2009.02.005.

Lawless HT, Heyman H. 2010. Sensory Evaluation of Food Principle and Practices. Edisi Kedua. 25. New York: Springer Science Business Media.
Manzocco L, Rumignani A, Lagazio C. 2013. Emotional response to fruit salads with different visual quality. Food Qual Prefer 28: 17-22. DOI: 10.1016/j.foodqual.2012.08.014.

Meilgaard MC, Civille GV, Carr BT. 2015. Sensory Evaluation Techniques. Edisi Kelima. 325-328. CRC Online Publisher, Boca Raton, Florida

Meyners M, Jaeger SR, Ares G. 2016. On the analysis of Rate-All-That-Apply (RATA) data. Food Qual Prefer 49: 1-10. DOI: 10.1016/j.food qual.2015.11.003.

Mora M, Urdaneta E, Chaya C. 2019. Effect of personality on the emotional response elicited by wines. Food Qual Prefer 76: 39-46. DOI: 10.1016/j.foodqual.2019.03.015.

Nestrud MA, Meiselman HL, King SC, Lesher LL, Cardello AV. 2016. Development of EsSense25, a shorter version of the EsSense Profile $\AA$. Food Qual Prefer 48: 107-117. DOI: 10.1016/j.foodqual.2015.08.005.

$\mathrm{Ng} \mathrm{M}$, Chaya C, Hort J. 2013. Beyond liking: Comparing the measurement of emotional response using EsSense profile and consumer defined check-all-that-apply methodologies. Food Qual Prefer 28: 193-205. DOI: 10.1016/j. foodqual.2012.08.012.

Rebin, Karsinah, Endriyanto. 2016. Status pengembangan mangga Garifta di kabupaten Pasuruan. IPTEK Hortik. (12): 75-80.

Samant SS, Chapko MJ, Seo HS. 2017. Predicting consumer liking and preference based on emotional responses and sensory perception: $\mathrm{A}$ study with basic taste solutions. Food Res Int 100: 325-334. DOI: 10.1016/j.foodres.2017.07. 021.

Samant SS, Seo HS. 2019. Using both emotional responses and sensory attribute intensities to predict consumer liking and preference toward vegetable juice products. Food Qual Prefer 73: 75-85. DOI: 10.1016/j.foodqual.2018.12.006.

Santagiuliana M, Bhaskaran V, Scholten E, Piqueras-Fiszman B, Stieger M. 2019. Don't judge new foods by their appearance! How visual and oral sensory cues affect sensory perception and liking of novel, heterogeneous foods. Food Qual Prefer 77: 64-77. DOI: 10.1016/j.foodqual.2019.05.005.

Schifferstein HNJ, Fenko A, Desmet PMA, Labbe D, Martin N. 2013. Influence of package design on the dynamics of multisensory and emotional food experience. Food Qual Prefer 27: 18-25. DOI: 10.1016/j.foodqual.2012.06.003. 
Spinelli S, Masi C, Dinnella C, Zoboli GP, Monteleone E. 2014. How does it make you feel? A new approach to measuring emotions in food product experience. Food Qual Prefer 37: 109-122. DOI: 10.1016/j.foodqual.2013.11.009.

Spinelli S, Monteleone E, Ares G, Jaeger SR. 2019. Sensory drivers of product-elicited emotions are moderated by liking: Insights from consumer segmentation. Food Qual Prefer 78: 103725. DOI: 10.1016/j.foodqual.2019.103725.

Sugiyono. 2019. Metode Penelitian Kuantitatif Kualitatif dan R\&D. Ed ke-2. 81-85. Alfabeta, Bandung.

Uswatun H, Dede R Adawiyah, Budi N. 2014. Preferensi dan ambang deteksi rasa manis dan pahit: pendekatan multikultural dan gender. $\mathrm{J}$ Mutu Pangan 1: 1-8.
Utami M, Wijaya CH, Efendi D, Adawiyah R. 2020. Karakteristik fisikokimia dan profil sensori mangga gedong pada dua tingkat kematangan. J Teknol Industri Pangan 31: 113-126. DOI: 10.6066/jtip.2020.31.2.113.

Waehrens SS, Grønbeck MS, Olsen K, Byrne D V. 2018. Impact of consumer associations, emotions, and appropriateness for use on food acceptability: A CATA and liking evaluation of vegetable and berry beverages. J Sens Stud 33: e12328. DOI: 10.1111/joss.12328.

Yang Q, Shen Y, Foster T, Hort J. 2020. Measuring consumer emotional response and acceptance to sustainable food products. Food Res Int 131: 108992. DOI: 10.1016/j.foodres.2020.108992. 